Jurnal Pengurusan 61(2021) $17-30$

https://doi.org/10.17576/pengurusan-2021-61-02

\title{
Perceived Risk and Trust in Purchase Intention towards Generic Drugs in Malaysia
}

\author{
(Risiko dan Kepercayaan dalam Kehendak untuk Membeli Ubat-ubatan Generik di Malaysia)
}

\author{
Hong Keai Sin \\ Kamisah Ismail \\ (Faculty of Business and Accountancy, University of Malaya)
}

ABSTRACT

This study aims to examine factors that influence purchase intention towards generic drugs in Malaysia. We proposed that perceived risk and trust are the determinants of purchase intention towards generic medicines. Self-administered questionnaires were distributed using both offline and online method. 283 responses were collected and analysed using SmartPLS version 3. The results showed that all six dimensions of perceived risk has significant influence on the intention to purchase generic drugs. Performance risk has the highest contribution towards perceived risk. Besides, the findings revealed that trust does not influence perceived risk but influence purchase intention. The results suggested that the mediation effect of perceived risk between trust and purchase intention is not significant. The findings provide significant implications to government, policy makers, pharmaceutical manufacturers and marketers in their quests to reduce the escalating pharmaceutical costs and to increase generic substitution rate.

Keywords: Perceived risk; trust; purchase intention; generic drugs.

ABSTRAK

Kajian ini bertujuan untuk mengkaji faktor-faktor yang mempengaruhi kehendak untuk membeli ubat-ubatan generik di Malaysia. Kami cadangkan bahawa risiko dan kepercayaan adalah penentu kehendak untuk membeli ubat-ubatan generik Tinjauan soal selidik telah diedarkan dengan menggunakan kaedah dalam dan luar talian. Sebanyak 283 balasan telah dikumpulkan dan dianalisa menggunakan SmartPLS versi 3. Hasil penyelidikan menunjukkan bahawa kesemua enam dimensi risiko mempengaruhi kehendak untuk membeli ubat-ubatan generik secara signifikan. Risiko prestasi mempunyai sumbangan tertinggi terhadap risiko. Selain itu, penemuan penyelidikan didapati bahawa kepercayaan tidak mempengaruhi risiko tetapi mempengaruhi kehendak untuk membeli. Hasil penyelidikan mencadangkan bahawa kesan mediasi risiko antara kepercayaan dan kehendak untuk membeli adalah tidak signifikan. Penemuan ini memberikan implikasi yang signifikan kepada kerajaan, penulis dasar, pengeluar dan syarikat pemasaran barangan farmaseutikal berkenaan dengan misi-misi bertujuan untuk mengurangkan kos farmaseutikal yang semakin meningkat serta mempertingkatkan kadar penggantian generik.

Kata kunci: Risiko; kepercayaan; kehendak untuk membeli; ubat generik.

\section{INTRODUCTION}

Globally, healthcare outlay has been increasing considerably in the past few decades. According to World Health Organization (2015), the world expended USD 7.3 trillion on healthcare, characterising nearly $10 \%$ of worldwide gross domestic product in 2015. Healthcare outlay is rising faster than the overall economy $(\mathrm{Xu}$ et al. 2018). In the context of healthcare industry, pharmaceutical expenditure have been related to second major driver for healthcare expenditure growth, after healthcare professionals' wages (Wong et al. 2014a). Similarly, pharmaceutical expenditures in Malaysia has risen from US\$ 1.55 billion (2010) to US\$ 2.11 billion (2013), characterising 36\% rise within 4 years' duration. Although with continuous effort by the Malaysian government to promote the generic substitution in the country, the prescription market is still dominated by brand name drugs, that comprised of about $60 \%$ of market share by value of prescription sales (Wong et al. 2014a). Besides, Frost and Sullivan, a business consulting firm, reported that the overall healthcare industry outlay in Malaysia, is forecasted to achieve RM80 billion by 2020 from RM52 billion at the end of 2017 (Zainul 2018). Hence, examining the trend of drug expenditure is crucial to ensure long term financial sustainability of the current health system. Generic drugs are identical medicines or are bioequivalent to patented drugs in terms of form, strength, dosage, safety, quality, route of administration, performance characteristics and their intended use. The costs of generic drugs are usually lower compared to equivalent branded drugs (Yousefi et al. 2015; Mahdi, et al. 2020). One of the methods to curb the escalating pharmaceutical outlay is by increasing generic substitution rate while the benefit of this mechanism of substitution with generic drugs has been confirmed in previous researches (Haas et al. 2005; Wong et al. 2014a). Generic substitution has become a common practice in several countries as it is considered as a major cost reducing strategy without compromising 
healthcare quality (Shraim et al. 2017; Nunes et al. 2020). In addition, substitution with generic drugs, which are pharmacologically comparable to the original drugs and are distributed to the market after the expiration of the patent of the original drug, not only minimises the pharmaceutical cost, it also helps in drug accessibility and affordability (Yousefi et al. 2015), and increases efficiency and sustainability in the health system (Nunes et al. 2020). The expenditure saved from generic substitution mechanism allows more patients to be treated with the same amount of expenditures and enable fund to be financed to other healthcare expenditures such as treatment and facilities.

Unfortunately, most of the doctors from private sectors in Malaysia have undesirable perceptions regarding safety, efficacy and the quality of generic drugs. These undesirable perceptions possibly the reason of poor generic substitution rate in the private healthcare sectors (Kumar et al. 2015; Mahdi et al. 2020). According to Shraim et al. (2017), general practitioners and healthcare professionals are most concern about safety and quality issues of generic drugs. Numerous studies have been carried out to investigate the perceptions and knowledge of community pharmacists, physician and general practitioners in Malaysia (Chua et al. 2010; Hassali et al. 2014a; Kumar et al. 2015) While there have been considerable interest and studies conducted on purchase intention towards generic drugs, most of these studies were concentrated in developed Western countries and little attention was paid to developing countries like Malaysia. It is expected that the results and factors influencing purchase intention could be different in developing countries due to differences in culture, perceptions, beliefs, and purchasing power. This study aims to bridge the gap in knowledge to explore the determinants influencing purchase intention towards generic drugs in Malaysia. Moreover, existing studies in both developed and developing countries focused on behavioral intention towards generic drugs among pharmacists and doctors, little or almost no studies have been done on patients and end consumers (Balasopoulos et al. 2017; Lewek et al. 2015; Masood et al. 2016; Wajid et al. 2015). On top of that, there is also little studies have been done on behavioral intention towards generic drugs from empirical marketing perspective. Prior studies on behavioral intention of generic drugs have been done using descriptive analysis method (Chua et al. 2010; Hassali et al. 2014a; Hassali et al. 2014c; Kumar et al. 2015; Kumar et al. 2014). Hence, this study aims to investigate the determinants that influence purchase intention towards generic drugs from empirical marketing perspective among Malaysians.

The lack of research on trust and purchase intention, as well as research examined the role of risk as a mediator, also motivate us to examine the mediating effect of perceived risk between trust and purchase intention towards generic drugs. Thus far, to the authors' knowledge, only Zerbini et al. (2017) examined the mediating effect of trust in pharmacist. However, their study used only two measures of risk: physical risk and performance risk, whereas our study measures the perceived using a more comprehensive measure that comprises six elements of risk: financial risk, performance risk, psychological risk, physical risk, social risk and time risk. It is expected that with a more comprehensive measure of risks, the results would be different and could contribute to the methodological aspect.

The objectives of this study are (1) to determine the dimension of perceived risk that are significantly associated with perceived risk toward generic drugs, (2) to examine the relationship between perceived risk and purchase intention towards generic drugs, (3) to examine the relationship between trust in pharmacist and perceived risk, (4) to examine the relationship between trust and purchase intention towards generic drugs and (5) to examine the mediating effect of perceived risk between trust and purchase intention towards generic drugs.

This paper will be organized in the following manner. The literature review and hypotheses development will be discussed in the next section, followed by research method, results and discussions. Then, theoretical and managerial implications are presented. Finally, this paper concludes with some limitations and suggestions for future research.

\section{LITERATURE REVIEW AND HYPOTHESES DEVELOPMENT}

\section{PERCEIVED RISK}

Perceived risk is defined as the degree to which one feels the uncertainty and consequences related with their action (Zerbini et al. 2017). Bauer (1967) defines perceived risk as a combination of uncertainty plus seriousness of outcome involved. On the other hand, Peter et al. (1976) describe perceived risk as the expectation of losses associated with purchase and acts as an inhibitor to purchase behaviour (Featherman \& Pavlou 2003). Perceived risk is also conceptualized as the consumer's subjective expectation of enduring a loss in quest of a favourable outcome (Chopdar et al. 2018). In this context, perceived risk denotes to the degree of uncertainty and the degree of unfavourable consequences when a consumer purchases generic drugs.

Perceived risk has been viewed as a multidimensional construct. According to Stone and Gronhaug (1993), there are six dimensions of perceived risk in the overall risk construct. The six dimensions are financial risk, performance risk, psychological risk, physical risk, social risk and time risk. Each dimensions may elucidate a portion of overall perceived risk and their relative importance may differ according to the context of study. Some risk dimensions might be more prevalent in certain purchase situations than in others. Similar to Stone and 
Gronhaug (1993), in the context of generic drugs in this study, we propose the following hypotheses:

$\mathrm{H}_{1}$ Perceived risk comprises the dimensions of (a) physical (b) financial (c) performance (d) time (e) social and (f) psychological risk.

$\mathrm{H}_{1 \mathrm{a}}$ Physical risk is positively related with perceived risk.

$\mathrm{H}_{1 \mathrm{~b}}$ Financial risk is positively related with perceived risk.

$\mathrm{H}_{1 \mathrm{c}}$ Performance risk is positively related with perceived risk.

$\mathrm{H}_{1 \mathrm{~d}}$ Time risk is positively related with perceived risk.

$\mathrm{H}_{1 \mathrm{e}}$ Social risk is positively related with perceived risk.

$\mathrm{H}_{1 \mathrm{f}}$ Psychological risk is positively related with perceived risk.

Purchase intention of generic drugs denotes the willingness of a customer to buy a generic drug product. Perceived risk of generic medicines refers to the uncertainty felt by consumer and the negative consequences encountered resulting from purchasing a generic medicine product. Perceived risk is a strong indicator for predicting the actual purchase decision. A numbers of authors have discerned that there is a negative relationship between perceived risk and behavioural intention (Chopdar et al. 2018; Forsythe \& Shi 2003; Kim et al. 2005). According to Rozano and Gomez (2009), perceived risk has a negative influence on request intention on generic drugs. Request intention refers to consumer's request for generic drugs from a prescriber (physician or pharmacist). In other words, the larger the perceived risk, the less the intention to request a generic drug from a prescriber. Zerbini et al. (2017) also showed that perceived risk for generic drugs negatively influences generic drugs purchase intention. Therefore, the following hypothesis is proposed:
$\mathrm{H}_{2}$ Perceived risk is negatively related with purchase intention towards generic drug

\section{TRUST IN PHARMACIST}

Trust in pharmacist possibly play an imperative part in purchase decision by educating consumers or patients regarding the presence of generic drugs (Leisen \& Hyman 2004; Zerbini et al., 2017). Trust is referred to as the willingness of trustor to count on trustee who has benevolence and credibility. In the context of this study, trust refers to willingness of a consumer or patient to rely on pharmacists. Pharmacists possess in-depth knowledge about drugs such as their bioequivalence and stability. Since pharmacists are seen as knowledgeable, expert and reliable in drugs, consumer's perceived risk of buying generic drugs will be reduced with their recommendation or prescription. It is expected that trust in pharmacist will positively affect consumer's purchase intention towards generic drugs, and trust is negatively related with perceived risk. The following hypotheses ensue:

$\mathrm{H}_{3}$ Trust in pharmacist is negatively related with perceived risk.

$\mathrm{H}_{4}$ Trust in pharmacist is positively related with purchase intention towards generic drugs.

\section{MEDIATING ROLE OF PERCEIVED RISK BETWEEN TRUST AND PURCHASE INTENTION}

Perceived risk refers to the uncertainty and the probability of loss encounters by a consumer as a result of purchasing a generic drug product (Peter et al. 1976; Zerbini et al. 2017). When the feeling of uncertainty and the perception of probability of loss is very high, it will mitigate the effect of trust in pharmacist on purchase intention (Zerbini et al. 2017). Therefore, perceived risk

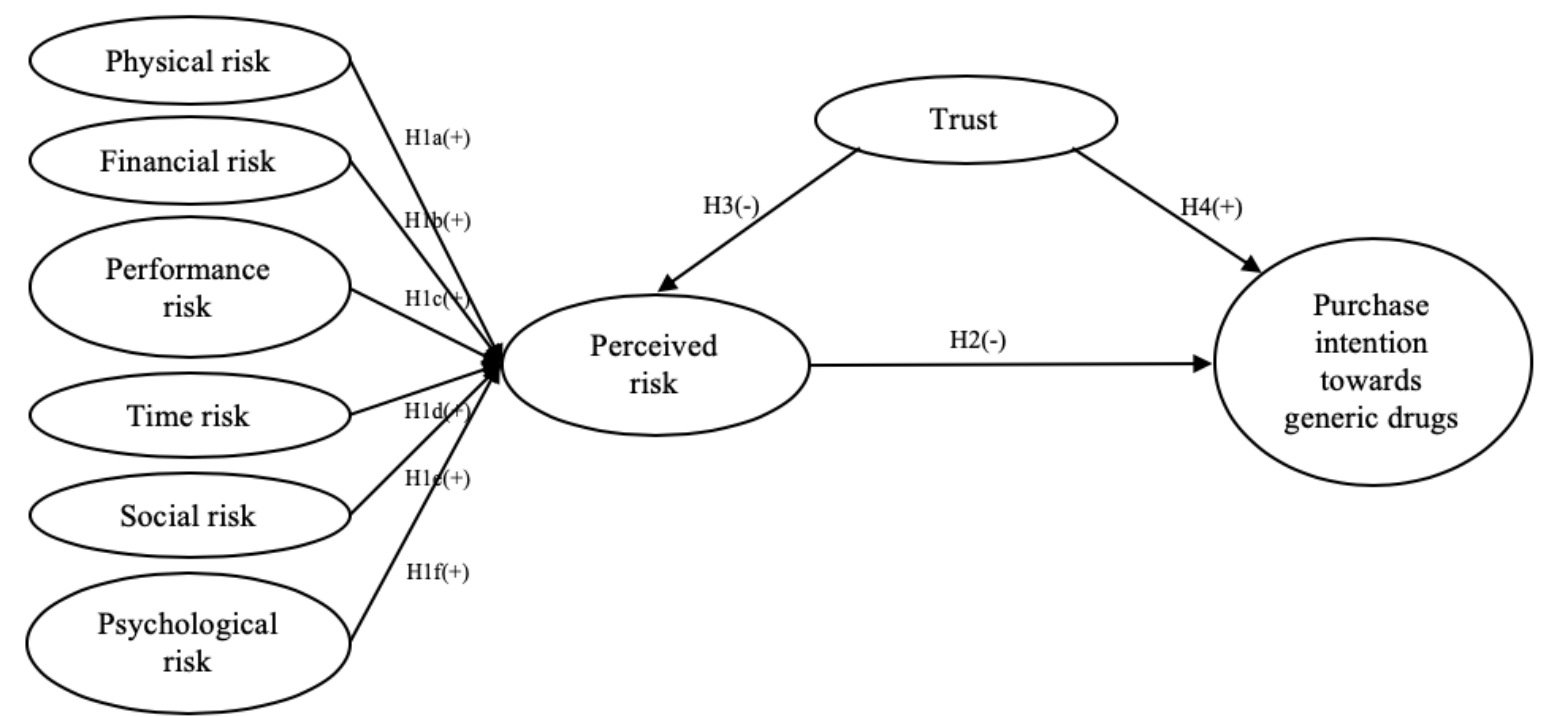

FIGURE 1. Research model 
towards generic drugs mediate the relationship between trust and purchase intention. The following hypothesis is suggested:

$\mathrm{H}_{5} \quad$ The effect of trust in pharmacist on the generic drugs purchase intention is mediated by the perceived risk for generic drugs.

\section{RESEARCH MODEL}

The research model for this study is shown in Figure 1. The model comprises perceived risk, trust in pharmacist and purchase intention towards generic drugs. The model also shows the mediating role of perceived risk between trust in pharmacist and purchase intention towards generic drugs. This research model was adapted and extended from Zerbini et al. (2017) and Abzakh et al. (2013).

\section{THEORY OF PLANNED BEHAVIOUR}

The research model shown in Figure 1 was developed based on Theory of Planned Behaviour (TPB) (Ajzen 1985). TPB denotes that an individual's behaviour is predicted by intention, and the intention is aggregately influenced by attitude, subjective norm, and perceived behavioural control pertaining to a particular behaviour. Since intention is defined as an expression of the consumer's will in terms of motivational effort to carry out a particular behaviour (Ajzen 1985, 1991; Cheng \& Huang 2013; Rozano \& Gomez 2009), intention is assumed to be the immediate factor of behaviour (Ajzen

TABLE 1. Measurement items

\begin{tabular}{|c|c|c|}
\hline Construct & Items & Measurement Items \\
\hline \multirow{3}{*}{$\begin{array}{l}\text { Purchase intention } \\
\text { towards generic drugs }\end{array}$} & PI1 & Assuming I had the opportunity, I would intend to buy generic medicines \\
\hline & PI2 & Given that I had the opportunity, I predict that I would buy generic medicines \\
\hline & PI3 & I will probably buy generic medicines in the near future \\
\hline \multirow[t]{3}{*}{ Physical risk } & PHY1 & $\begin{array}{l}\text { One concern I have about purchasing generic drugs is that the risk of endangering my } \\
\text { health might be high. }\end{array}$ \\
\hline & PHY2 & $\begin{array}{l}\text { I am concerned about potential physical risks associated with the consumption of generic } \\
\text { drugs. }\end{array}$ \\
\hline & PHY3 & I have confidence concerns in the case of consuming generic drugs. \\
\hline \multirow[t]{3}{*}{ Financial risk } & FR1 & I would be concerned that buying generic medicines would not be wise. \\
\hline & FR2 & I can spend my money in a better way rather than buying generic medicines. \\
\hline & FR3 & I would be concerned that I would not get my money's worth from the generic medicines. \\
\hline \multirow[t]{3}{*}{ Performance risk } & PER1 & $\begin{array}{l}\text { As I consider the purchase of generic medicines, I worry whether or not the medicines will } \\
\text { really perform as well as it is supposed to. }\end{array}$ \\
\hline & PER2 & $\begin{array}{l}\text { If I were to purchase a generic medicine, I become concerned that it will not provide the } \\
\text { level of benefits that I would be expecting. }\end{array}$ \\
\hline & PER3 & $\begin{array}{l}\text { The thought of purchasing a generic medicine causes me to be concerned for how really } \\
\text { dependable and reliable that product will be. }\end{array}$ \\
\hline \multirow[t]{2}{*}{ Time risk } & TR1 & $\begin{array}{l}\text { The purchase of generic medicines would create even more time pressure on me that I } \\
\text { don't need. }\end{array}$ \\
\hline & TR2 & $\begin{array}{l}\text { The purchase of generic medicines makes me concerned because, to understand the } \\
\text { medicines characteristics and differences, might lead to an inefficient use of my time. }\end{array}$ \\
\hline \multirow[t]{2}{*}{ Social risk } & SR1 & $\begin{array}{l}\text { The purchase of generic medicines would cause some people whose opinions I value to } \\
\text { perceive me as calculative person. }\end{array}$ \\
\hline & $\mathrm{SR} 2$ & My friends would think I was just being price-conscious by buying generic medicines. \\
\hline \multirow[t]{3}{*}{ Psychological risk } & PSY1 & The thought of purchasing generic medicines causes me to experience unnecessary tension. \\
\hline & PSY2 & $\begin{array}{l}\text { The thought of purchasing generic medicines makes me feel psychologically } \\
\text { uncomfortable. }\end{array}$ \\
\hline & PSY3 & The thought of purchasing generic medicines makes me feel worried. \\
\hline \multirow{3}{*}{$\begin{array}{l}\text { Trust in pharmacist or } \\
\text { physician }\end{array}$} & TRU1 & How much can you count on the pharmacist/physician? \\
\hline & TRU2 & How much do you trust the pharmacist/physician? \\
\hline & TRU3 & How dependable is the pharmacist/physician? \\
\hline
\end{tabular}


1985, 1991, 2010). Consequently, purchase intention is an effective means of predicting purchase behaviour (Jaafar et al. 2013). In this study, behaviour of purchasing generic drugs is predicted by purchase intention towards generic drugs.

\section{METHOD}

\section{SAMPLE AND DATA COLLECTION}

A survey was conducted among respondents who have purchased drugs for personal use in the past. Pilot and pre-tests were conducted to gather feedbacks and comments from potential respondents and academicians prior to data collection. Convenience sampling technique was employed in this study. Both physical and online questionnaires were distributed to public and private hospitals in Klang Valley. 329 responses were gathered over four weeks. Missing data were not replaced since it comprised less than $0.05 \%$ of collected data and suspicious data were eliminated. Responses were filtered based on two screening criteria: only respondents who (1) answered correctly about what are generic drugs and (2) have purchased drugs for personal use in the past were retained, leaving 283 valid responses for analysis. The minimum required sample size was 76 (using the medium effect size of 0.15 , probability level of 0.05 and statistical power level of 0.8) (Soper 2018). Therefore, 283 responses were retained and considered as adequate.

\section{MEASUREMENT OF VARIABLES}

The measurement items used in the questionnaire were developed based on prior studies. Purchase intention towards generic drugs was measured by a bipolar scale adapted from Degirmenci and Breitner (2017). Measurement for perceived risk were adapted from Abzakh et al. (2013) and Wiedmann et al. (2011). Items for trust in pharmacist or physician were developed from Zerbini et al. (2017) and Thomson (2006). All items were measured using a five-point Likert scale ranging from 1 (strongly disagree) to 5 (strongly agree). Table 1 shows the measurement items used in the questionnaire.

\section{ANALYSIS METHOD}

Descriptive analysis was done using IBM Statistical Package for Social Sciences (SPSS) version 22 while estimation of research model was done using SmartPLS 3.2.8, which adopt partial least squares structural equation modelling (PLS-SEM) method due to its capability to estimate models for non-parametric data, and its ability to estimate both formative and reflective constructs simultaneously. In addition, PLS-SEM that focuses on prediction is also able to analyse small sample size and complex structural model with many constructs and indicators (Hair et al. 2012).

\section{RESULTS}

\section{DESCRIPTIVE ANALYSIS}

Table 2 summarises the respondents' demographic profile. As shown in Table 2, the proportion of gender between male and female is almost equal. Majority of respondents $(74.5 \%)$ were in the age group between 26 to 45 , followed by age group between 46 to 55 (18\%). The respondents comprised of 29\% Malay, $50 \%$ Chinese, $20 \%$ Indian, and $1 \%$ other races. Majority of respondents (82\%) were middle income earners to uppermiddle income earners (RM5,000 and above). 52\% of respondents surveyed purchase medicines sometimes in a year, $42 \%$ of respondents purchase medicines once or twice a month, $3 \%$ of respondents buy medicines once a week and $3 \%$ of respondents purchase medicines more

TABLE 2. Summary of respondents' demographic profile $(\mathrm{N}=283)$

\begin{tabular}{|c|c|c|}
\hline Variables & Frequency $(\mathrm{N})$ & Percentage $(\%)$ \\
\hline \multicolumn{3}{|l|}{ Gender } \\
\hline Male & 139 & 49.1 \\
\hline Female & 144 & 50.9 \\
\hline \multicolumn{3}{|l|}{ Age (years) } \\
\hline $18-25$ & 6 & 2.1 \\
\hline $26-35$ & 109 & 38.5 \\
\hline $36-45$ & 102 & 36.0 \\
\hline $46-55$ & 52 & 18.4 \\
\hline 56 and above & 14 & 4.9 \\
\hline \multicolumn{3}{|l|}{ Ethnicity } \\
\hline Malay & 83 & 29.3 \\
\hline Chinese & 141 & 49.8 \\
\hline Indian & 58 & 20.5 \\
\hline Others & 1 & 0.4 \\
\hline \multicolumn{3}{|l|}{ Monthly individual income } \\
\hline RM4,999 and below & 52 & 18.4 \\
\hline RM5,000 - RM9,999 & 105 & 37.1 \\
\hline RM10,000 - RM14,999 & 62 & 21.9 \\
\hline RM15,000 - RM19,999 & 11 & 3.9 \\
\hline RM20,000 and above & 53 & 18.7 \\
\hline \multicolumn{3}{|c|}{ Medicine purchasing behaviour } \\
\hline Sometimes a year & 147 & 51.9 \\
\hline Once or twice a month & 118 & 41.7 \\
\hline Once a week & 9 & 3.2 \\
\hline More than once a week & 9 & 3.2 \\
\hline \multicolumn{3}{|l|}{ Health status evaluation } \\
\hline Excellent & 70 & 24.7 \\
\hline Good & 171 & 60.4 \\
\hline Neither good nor bad & 41 & 14.5 \\
\hline Poor & 1 & 0.4 \\
\hline
\end{tabular}


TABLE 3. Evaluation of first order reflective measures $(n=283)$

\begin{tabular}{|c|c|c|c|c|c|}
\hline Constructs & Items & Loadings & Cronbach's Alpha & $\mathrm{CR}$ & AVE \\
\hline \multirow[t]{3}{*}{ FR } & FR1 & 0.791 & 0.727 & 0.846 & 0.647 \\
\hline & FR2 & 0.785 & & & \\
\hline & FR3 & 0.836 & & & \\
\hline \multirow[t]{3}{*}{ PER } & PER1 & 0.930 & 0.862 & 0.916 & 0.785 \\
\hline & PER2 & 0.872 & & & \\
\hline & PER3 & 0.854 & & & \\
\hline \multirow[t]{3}{*}{ PHY } & PHY1 & 0.860 & 0.755 & 0.860 & 0.674 \\
\hline & PHY2 & 0.877 & & & \\
\hline & PHY3 & 0.717 & & & \\
\hline \multirow[t]{3}{*}{ PSY } & PSY1 & 0.792 & 0.744 & 0.856 & 0.665 \\
\hline & PSY2 & 0.742 & & & \\
\hline & PSY3 & 0.905 & & & \\
\hline \multirow[t]{3}{*}{ PI } & PI1 & 0.949 & 0.878 & 0.926 & 0.806 \\
\hline & PI2 & 0.904 & & & \\
\hline & PI3 & 0.836 & & & \\
\hline \multirow[t]{2}{*}{ SR } & SR1 & 0.855 & 0.742 & 0.884 & 0.792 \\
\hline & SR2 & 0.923 & & & \\
\hline \multirow[t]{2}{*}{ TR } & TR1 & 0.884 & 0.674 & 0.859 & 0.754 \\
\hline & TR2 & 0.852 & & & \\
\hline \multirow[t]{2}{*}{ TRU } & TRU1 & 0.855 & 0.600 & 0.833 & 0.714 \\
\hline & TRU2 & 0.835 & & & \\
\hline
\end{tabular}

Notes: $\mathrm{FR}=$ financial risk, $\mathrm{PHY}=$ Physical Risk, $\mathrm{PER}=$ Performance Risk, PSY $=$ Psychological Risk, $\mathrm{SR}=\mathrm{Social}$ Risk, $\mathrm{TR}=\mathrm{Time}$ Risk, $\mathrm{TRU}=$ Trust, PI = Purchase Intention, CR = Composite Reliability, AVE = average variance extracted. Item TRU3 was deleted due to low loadings.

than once a week. $25 \%$ of respondents consider their health status as excellent, $60 \%$ of respondents were self-evaluated as good, $14 \%$ of respondents think their health status was neither good nor bad while only $1 \%$ of respondents evaluated their health as poor.

\section{MEASUREMENT MODEL EVALUATION}

\section{FIRST ORDER REFLECTIVE MEASURE}

The indicator loadings, composite reliability (CR) as well as average variance extracted (AVE) of the reflective constructs were assessed (see Table 3). Outer loadings, Cronbach's alpha, CR, and AVE for each item were scrutinized. All loadings that are above the recommended magnitude of 0.70 are kept (Hair et al. 2014). Item TRU3 was removed due to low loading. It is deduced that all variables fulfilled the requirement of reliability and convergent validity.

Next, discriminant validity of the model is evaluated. Items should load more strongly on their own constructs than on other constructs in the model. The average variance shared between each construct and its items should be greater compared to the average variance shared between one construct and other constructs
(Fornell \& Larcker 1994). All variables exhibit adequate and satisfactory discriminant validity, where the square root of AVE (diagonal) is greater than the correlations (off-diagonal) for all reflective constructs (see Table 4).

\section{SECOND ORDER FORMATIVE CONSTRUCT}

Six dimensions of perceived risk (financial risk, performance risk, physical risk, psychological risk, time risk and social risk) are established as hierarchical component model (HCM). Two-stage HCM analysis was applied in which latent variable scores for lower-order components is obtained by using repeated indicator approach in the first stage while latent variable scores for lower-order component will be treated as manifest variables in the higher-order component measurement model in the second stage.

Multicollinearity between first-order constructs were assessed. Based on the result shown in Table 5, all firstorder constructs met the criterion of VIF values which are below 5.0 (Hair et al. 2017) and also 3.3 (Diamantopoulos \& Siguaw 2006), indicating that the items are distinct and not correlated, thus meet the requirement as formative measures. Hence, it is deduced that collinearity does not reach critical levels in second-order construct and is not a problem for PLS path model estimation. 
TABLE 4. Discriminant validity using Fornell and Larcker criterion

\begin{tabular}{ccccccccc}
\hline & FR & PER & PHY & PSY & PI & SR & TR & TRU \\
\hline FR & 0.804 & & & & & & & \\
PER & 0.466 & 0.886 & & & & & & \\
PHY & 0.595 & 0.613 & 0.821 & & & & & \\
PSY & 0.625 & 0.463 & 0.563 & 0.816 & & & & \\
PI & -0.568 & -0.670 & -0.625 & -0.515 & 0.898 & & & \\
SR & 0.449 & 0.300 & 0.446 & 0.499 & -0.455 & 0.890 & & \\
TR & 0.500 & 0.549 & 0.532 & 0.51 & -0.695 & 0.313 & 0.868 & 0.845 \\
TRU & 0.107 & 0.059 & 0.056 & 0.133 & 0.001 & 0.093 & 0.045 & 0.093 \\
\hline
\end{tabular}

Notes: Diagonals represent the square root of the AVE while the off-diagonals represent the correlations. FR $=$ Financial Risk, PER $=$ Performance Risk, $\mathrm{PHY}=$ Physical Risk, PSY $=$ Psychological Risk, PI $=$ Purchase Intention, $\mathrm{SR}=$ Social Risk, $\mathrm{TR}=$ Time Risk, TRU $=$ Trust.

TABLE 5. Evaluation of second-order formative model

\begin{tabular}{lcccc}
\hline Second order construct & First order construct & Outer loadings & $p$-value & VIF \\
\hline Perceived Risk & FR & 0.706 & $<0.001^{*}$ & 2.001 \\
& PHY & 0.769 & $<0.001^{*}$ & 2.194 \\
PER & 0.824 & $<0.001^{*}$ & 1.822 \\
PSY & 0.644 & $<0.001^{*}$ & 2.035 \\
SR & 0.566 & $<0.001^{*}$ & 1.433 \\
TR & 0.852 & $<0.001^{*}$ & 1.716 \\
\hline
\end{tabular}

Notes : VIF $=$ variance inflation factor. $\mathrm{FR}=$ Financial Risk, PER $=$ Performance Risk, PHY $=$ Physical Risk, PSY $=$ Psychological Risk, SR $=$ Social Risk, and TR $=$ Time Risk. * p-value $<0.05$.

\section{STRUCTURAL MODEL EVALUATION}

\section{DIMENSIONS OF PERCEIVED RISK}

Table 6 depicts the result of lateral collinearity test. All values of inner VIF for all six dimensions of perceived risk (performance risk, financial risk, psychological risk, physical risk, social risk and time risk) that need to be scrutinized for lateral collinearity are smaller than 5.0, indicating lateral collinearity is not a concern in the study (Hair et al. 2017).

TABLE 6. Lateral collinearity assessment for perceived risk

\begin{tabular}{|c|c|c|c|c|c|c|c|}
\hline & \multicolumn{7}{|c|}{ Inner VIF } \\
\hline & FR & PR & PER & PHY & PSY & SR & TR \\
\hline FR & & 2.002 & & & & & \\
\hline \multicolumn{8}{|l|}{ PR } \\
\hline PER & & 1.822 & & & & & \\
\hline PHY & & 2.195 & & & & & \\
\hline PSY & & 2.036 & & & & & \\
\hline SR & & 1.433 & & & & & \\
\hline TR & & 1.715 & & & & & \\
\hline
\end{tabular}

The significance level and t-statistics for all paths were then calculated using SmartPLS 3.2.8 bootstrapping function. Based on Table 7 and Figure 2, the path coefficient assessment of six relationships between PR and its dimensions were observed to have t-value $\geq 2.33$, and level of significance at $1 \%$. The results show that performance risk has the highest contribution $(\beta=0.270$, $\mathrm{p}<0.01)$ to perceived risk construct and it was followed by physical risk $(\beta=0.252, \mathrm{p}<0.01)$, psychological risk $(\beta=0.238, p<0.01)$, financial risk $(\beta=0.231, \mathrm{p}<$ $0.01)$, time risk $(\beta=0.162, \mathrm{p}<0.01)$ and social risk $(\beta=$ $0.142, \mathrm{p}<0.01)$. Thus, $\mathrm{H}_{1 \mathrm{a}}, \mathrm{H}_{1 \mathrm{~b}}, \mathrm{H}_{1 \mathrm{c}}, \mathrm{H}_{1 \mathrm{~d}}, \mathrm{H}_{1 \mathrm{e}}$ and $\mathrm{H}_{1 \mathrm{f}}$ are supported.

\section{MAIN PATH MODEL}

Table 8 illustrates the outcome of lateral collinearity test for main path model. All inner VIF values for the main constructs (perceived risk, purchase intention and trust) that need to be examined for lateral multicollinearity are less than 5.0, indicating lateral multicollinearity is not a concern in the study (Hair et al., 2017).

In this study, three direct hypotheses were developed between constructs. According to the evaluation of the path coefficient as shown in Table 9 and Figure 3, two out of three relationships were observed to be significant. The paths from the perceived risk construct to purchase intention construct (PR -> PI) was observed to have t-value 
TABLE 7. Hypotheses testing for dimensions of perceived risk

\begin{tabular}{|c|c|c|c|c|c|c|c|c|}
\hline \multirow{2}{*}{ Hypothesis } & \multirow{2}{*}{ Relationship } & \multirow{2}{*}{ Standard Beta } & \multirow{2}{*}{ Standard Error } & \multirow{2}{*}{ t-value } & \multirow{2}{*}{ p-value } & \multirow{2}{*}{ Decision } & \multicolumn{2}{|c|}{ Confidence Interval } \\
\hline & & & & & & & $5 \%$ & $95 \%$ \\
\hline $\mathrm{H}_{\mathrm{la}}$ & PHY -> PR & 0.252 & 0.012 & $21.884 *$ & $<0.01$ & Supported & 0.234 & 0.273 \\
\hline $\mathrm{H}_{1 \mathrm{~b}}$ & FR $->$ PR & 0.231 & 0.011 & $20.118^{*}$ & $<0.01$ & Supported & 0.213 & 0.251 \\
\hline $\mathrm{H}_{1 \mathrm{c}}$ & PER -> PR & 0.270 & 0.013 & $20.918^{*}$ & $<0.01$ & Supported & 0.251 & 0.294 \\
\hline $\mathrm{H}_{1 \mathrm{~d}}$ & TR $->$ PR & 0.162 & 0.009 & $17.561^{*}$ & $<0.01$ & Supported & 0.148 & 0.178 \\
\hline $\mathrm{H}_{1 \mathrm{e}}$ & SR $->$ PR & 0.142 & 0.010 & $14.225^{*}$ & $<0.01$ & Supported & 0.126 & 0.159 \\
\hline $\mathrm{H}_{1 \mathrm{f}}$ & PSY -> PR & 0.238 & 0.013 & $18.843 *$ & $<0.01$ & Supported & 0.218 & 0.261 \\
\hline
\end{tabular}

Note: $\mathrm{FR}=$ Financial Risk, $\mathrm{PER}=$ Performance Risk, $\mathrm{PHY}=$ Physical Risk, $\mathrm{PSY}=$ Psychological Risk, $\mathrm{SR}=$ Social Risk, and TR $=$ Time Risk. ${ }^{*} \mathrm{p}<0.01$.

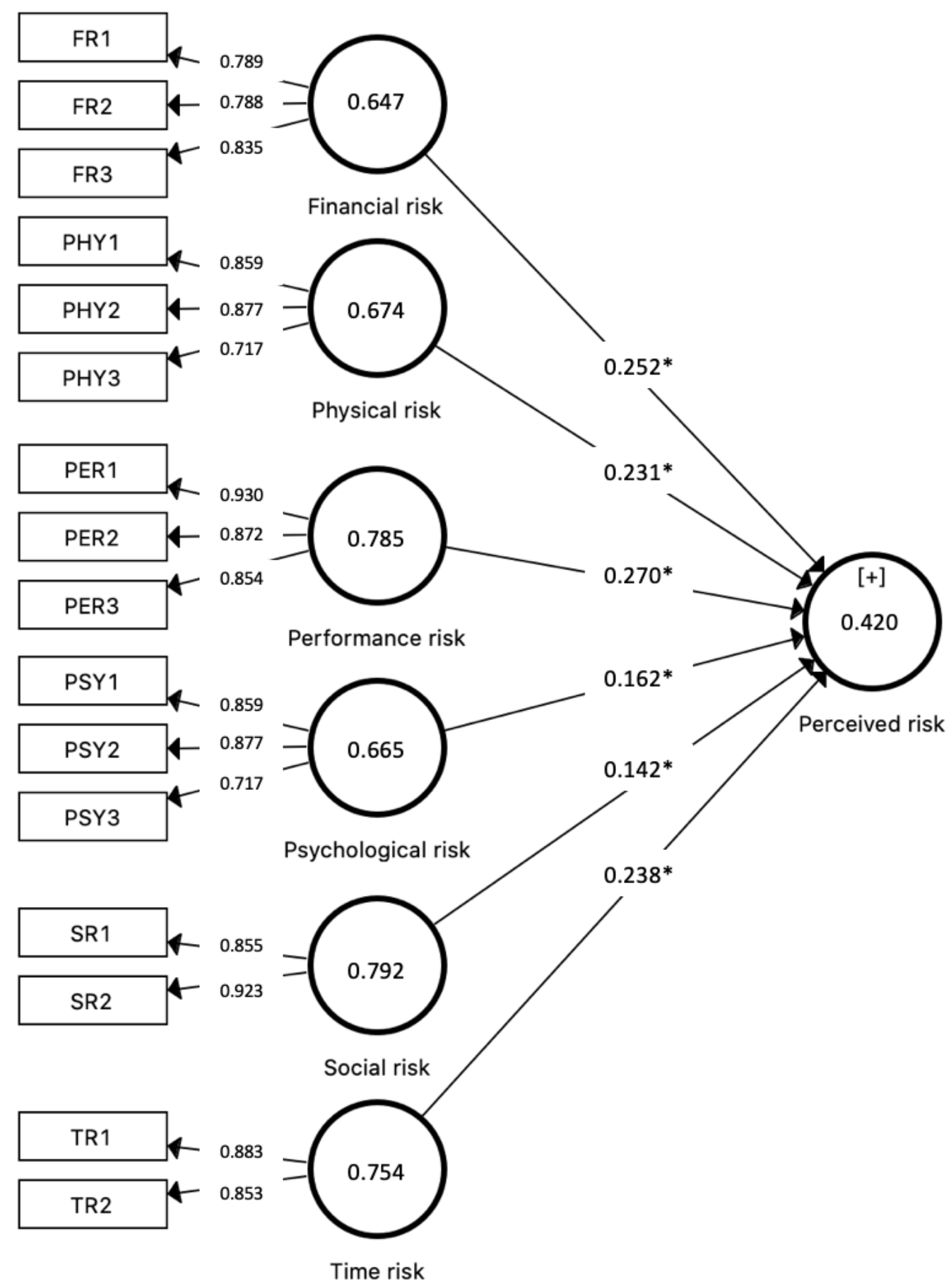

FIGURE 2. Structural model assessment for dimensions of perceived risk $(* \mathrm{p}<0.01)$ 
$\geq 2.33$, and $p$-value less than 0.01 level of significance ( $p$ $<0.01$ ) while the path from trust construct to purchase intention construct (TRU -> PI) were found to have $\mathrm{t}$-value $\geq 1.645(\mathrm{p}<0.05)$. The path from trust construct to perceived risk construct (TRU -> PR) was found to be not significant $(\mathrm{p}>0.1)$. Specifically, perceived risk that explained $69.7 \%$ of variance in purchase intention, was negatively related to purchase intention $(\beta=-0.839$, $\mathrm{p}<0.01)$. Thus, $\mathrm{H}_{2}$ is supported. The $\mathrm{R}^{2}$ value of 0.697 is above 0.26 value as recommended by Cohen (1988) indicating a substantial model. However, the negative relationship of trust construct and perceived risk construct was not significant $\left(\beta=0.072, \mathrm{p}>0.05, \mathrm{R}^{2}=\right.$ $0.004)$, while the relationship between trust construct and purchase intention construct was significant $(\beta=0.076$, $\mathrm{p}<0.05)$. Thus, $\mathrm{H}_{2}$ and $\mathrm{H}_{4}$ are supported while $\mathrm{H} 3$ is not supported.

Subsequently, the effect of sizes $\left(\mathrm{f}^{2}\right)$ were measured. According to Sullivan and Feinn (2012), p-value only indicates if the effect exists but does not reveal the size of the effect. The effect of size (substantive significance) and p-value (statistical significance) are key results to be stated in reporting and interpreting studies. Cohen's (1988) guideline is employed to assess the effect of size. The values of $0.02,0.15$ and 0.35 indicate small, medium, and large effects respectively (Cohen 1988). Based on
TABLE 8. Lateral collinearity assessment for Main Path Model

\begin{tabular}{cccc}
\hline & \multicolumn{3}{c}{ Inner VIF } \\
\cline { 2 - 4 } & PR & PI & TRU \\
\hline PR & & 1.008 & \\
PI & & & \\
TRU & 1.000 & 1.008 & \\
\hline
\end{tabular}

Note: $\mathrm{VIF}=$ variance inflation factor, $\mathrm{PR}=$ Perceived Risk, $\mathrm{PI}=$ Purchase Intention, TRU $=$ Trust.

Table 9, it can be observed that perceived risk (2.323) has a large effect in producing $\mathrm{R}^{2}$ for purchase intention $(0.697)$ while trust $(0.019)$ has no effect in producing $R^{2}$ for purchase intention (0.697). Similarly, trust (0.008) has no effect in producing $\mathrm{R}^{2}$ for perceived risk (0.004).

In addition, the predictive relevance of this research model was assessed using blindfolding procedure. Blindfolding procedure is a resampling method which systematically removes and estimates every data point of the items in the reflective measurement model of endogenous construct. This method is applied to compare the original values with the predicted values. In the event of the prediction is close to original values, which indicates small prediction error, the path model has a high prediction accuracy. If the Q2 value is larger than

TABLE 9. Hypotheses testing on Main Path Model

\begin{tabular}{|c|c|c|c|c|c|c|c|c|c|c|c|}
\hline \multirow{2}{*}{ Hypothesis } & \multirow{2}{*}{ Relationship } & \multirow{2}{*}{$\begin{array}{c}\text { Std } \\
\text { Beta }\end{array}$} & \multirow{2}{*}{$\begin{array}{c}\text { Std } \\
\text { Error }\end{array}$} & \multirow{2}{*}{ t-value } & \multirow{2}{*}{$\mathrm{p}$-value } & \multirow{2}{*}{ Decision } & \multicolumn{2}{|c|}{ Confidence Interval } & \multirow{2}{*}{$\mathrm{R}^{2}$} & \multirow{2}{*}{$f^{2}$} & \multirow[t]{2}{*}{$O^{2}$} \\
\hline & & & & & & & $5 \%$ & $95 \%$ & & & \\
\hline $\mathrm{H}_{2}$ & PR -> PI & -0.839 & 0.021 & $40.656^{* *}$ & $<0.01$ & Supported & -0.864 & -0.794 & 0.697 & 2.323 & 0.530 \\
\hline $\mathrm{H}_{3}$ & TRU -> PR & 0.089 & 0.072 & 1.236 & 0.109 & Not supported & -0.117 & 0.167 & 0.004 & 0.008 & 0.005 \\
\hline $\mathrm{H}_{4}$ & TRU -> PI & 0.076 & 0.045 & $1.683^{*}$ & 0.047 & Supported & -0.005 & 0.141 & & 0.019 & \\
\hline
\end{tabular}

Note: $\mathrm{PR}=$ Perceived Risk, $\mathrm{PI}=$ Purchase Intention, $\mathrm{TRU}=$ Trust, $\mathrm{R}^{2}=$ Coefficient of determination, $\mathrm{f}^{2}=$ effect size to $\mathrm{R}^{2}, \mathrm{Q}^{2}=$ Predictive Relevance. $* * \mathrm{p}<0.01, * \mathrm{p}<0.05$.

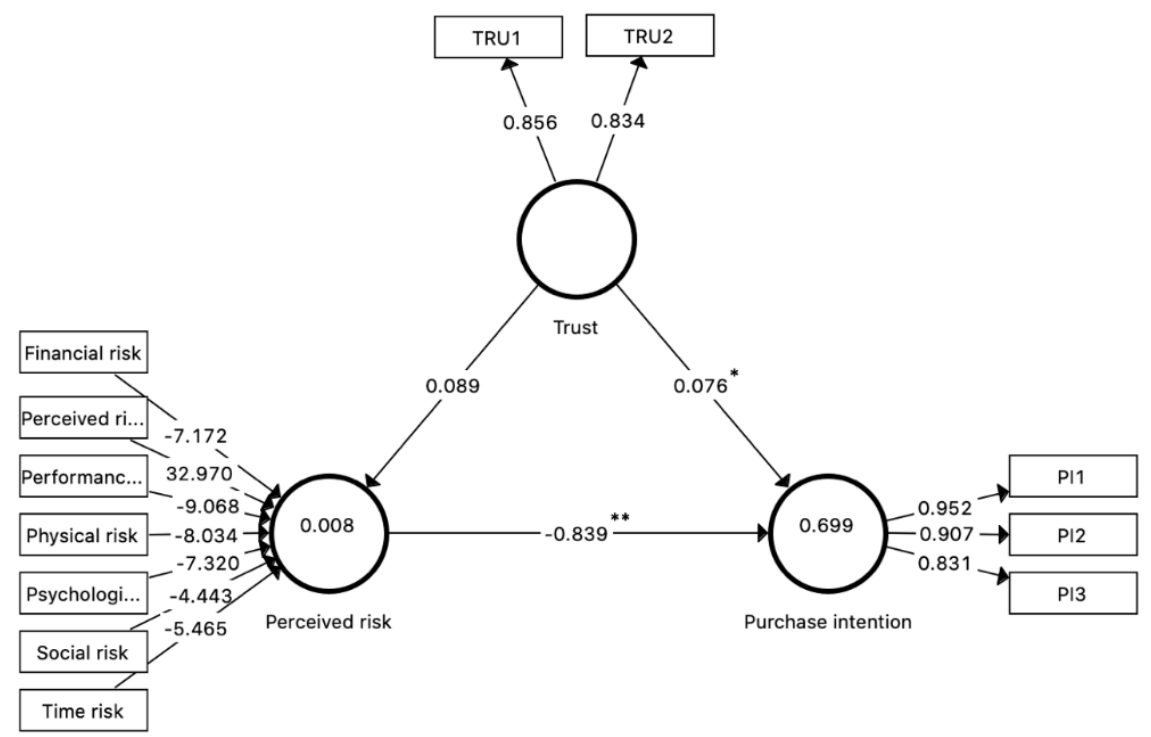

FIGURE 3. Structural model assessment for main path model $(* \mathrm{p}<0.01)$ 
0 , the model has predictive relevance for an endogenous construct (Fornell \& Cha 1994; Hair et al. 2017). Both Q2 values for purchase intention $(\mathrm{Q} 2=0.530)$ and perceived risk $(\mathrm{Q} 2=0.005)$ are more than 0 , indicating that the model has an adequate predictive relevance.

\section{ASSESSMENT OF MEDIATION ANALYSIS}

The result of mediation analysis was presented in Table 10. The bootstrapping of mediation analysis shows that the indirect effect (Trust $->$ Perceived Risk -> Purchase Intention) was not significant with t-value less than 1.96 $(p>0.05)$. The $95 \%$ confidence interval of indirect effect of Bias-Corrected bootstrap [LL $=-0.135, \mathrm{UL}=0.011]$ overlaps a zero in between both indexes, indicating there is no mediation (Preacher \& Hayes 2004, 2008) formal significance tests of indirect effects are rarely conducted. After a brief overview of mediation, we argue the importance of directly testing the significance of indirect effects and provide SPSS and SAS macros that facilitate estimation of the indirect effect with a normal theory approach and a bootstrap approach to obtaining confidence intervals, as well as the traditional approach advocated by Baron and Kenny (1986. Thus, we can conclude that the mediation effect is not statistically significant. Therefore, $\mathrm{H}_{5}$ was not supported.

\section{DISCUSSION}

Structural model evaluation revealed that all six dimensions of perceived risk were significantly related with perceived risk. Performance risk has the highest contribution to perceived risk construct and it was followed by physical risk, psychological risk, financial risk, time risk and social risk. Performance risk, which is also known as functional risk, in the context of generic drugs purchase intention refers to the degree of possibility that the generic drugs purchased may end up failing to function as expected. Performance risk is created when there is a difference between consumer's expectation and actual performance of generic drugs (Abzakh et al. 2013; Chiu et al. 2014; Forsythe \& Shi 2003; González \& Brea 2008). The main objective of medicine consumption is to improve healing and recovery from certain illnesses. Rationally, consumers are expecting to recover after the administration of drugs. Therefore, the performance of the drugs has become the main concern when consumers are making purchase decision in buying drugs. This finding is consistent with past research by Abzakh et al. (2013). However, the significant result of financial risk, time risk, social risk and psychological risk is contradicting with previous findings by Abzakh et al. (2013) who found no significant association between financial risk, time risk, social risk and psychological risk with consumer resistance to generic drugs.

The results from path analysis showed that perceived risk is negatively related with purchase intention. When consumer perceived buying generic drugs has high risk, there will be low intention to purchase generic drugs. Since perceived risk is defined as the expectation of losses associated with purchase, it acts as an inhibitor to purchase behaviour (Featherman \& Pavlou 2003). This result is consistent with previous studies by Chopdar et al. (2018)we adapt the Unified Theory of Acceptance and Use of Technology 2 (UTAUT2, Forsythe and Shi (2003), and González and Brea (2008) that there is a negative relationship between perceived risk and behavioural intention. The negative influence of perceived risk on purchase intention corroborating its substantial role in purchase decision making process. Furthermore, in the context of medicines, past research also showed that perceived risk for generic drugs negatively influences generic drugs purchase intention (Zerbini et al. 2017).

The results also revealed that there is no significant mediation effect of perceived risk between trust in pharmacist and generic drugs purchase intention. This provides evidence that perceived risk plays no role in mitigating trust in pharmacist to motivate and encourage consumers to buy generic drugs. This insignificant finding showed that the relationship between perceived risk and trust in influencing the purchase intention towards generic medicines are distinctive to each other. This finding is contradict with previous study by Zerbini et al. (2017) who suggested that perceived risk towards generic drug can mediate relationship between trust and purchase intention thus reducing the impact of trust on intention.

\section{THEORETICAL IMPLICATION}

The findings of this study contribute to the literature by expanding the existing literature on consumer behaviour in the context of generic drugs. This study examines the determinants of purchase intention toward generic drugs among Malaysian. These results are vital because prior studies were conducted in developed countries (mostly in western countries) (Awaisu et al. 2014; Colgan et al. 2015; Ferreira \& Barbosa 2017; Francisquinho 2013; Khadke \& Khanda 2017; Masood et al. 2016; Shraim et al. 2017; Srivastava \& Kumar 2014; Wajid et al. 2015) consumers' and health care providers' perception and

TABLE 10. Hypotheses Testing on Mediation

\begin{tabular}{|c|c|c|c|c|c|c|c|c|}
\hline \multirow{2}{*}{ Hypothesis } & \multirow{2}{*}{ Relationship } & \multirow{2}{*}{ Std. Beta } & \multirow{2}{*}{ Std. Error } & \multirow{2}{*}{ t-value } & \multirow{2}{*}{ p-value } & \multicolumn{2}{|c|}{ Confidence Interval (BC) } & \multirow{2}{*}{ Decision } \\
\hline & & & & & & LL & UL & \\
\hline $\mathrm{H}_{5}$ & TRU -> PR -> PI & -0.058 & 0.038 & 1.553 & 0.121 & -0.135 & 0.011 & Not supported \\
\hline
\end{tabular}

Note: $\mathrm{BC}=$ Bias corrected, $\mathrm{LL}=$ Lower Limit, $\mathrm{UL}=$ Upper Limit, $\mathrm{PR}=$ Perceived Risk, $\mathrm{PI}=$ Purchase Intention, TRU $=$ Trust. * $\mathrm{p}<0.01$. 
attitude towards generic medicine act as a main barrier to the promotion of generic medicines. Objective: To explore the factors community pharmacists consider while dispensing branded or generic medicines to consumers. Method: A qualitative study was planned; twenty community pharmacists (ten hospital affiliated pharmacies and ten non-hospital affiliated pharmacies. Research looking at consumers' perspective on purchase intention among Malaysians is very much lacking. Furthermore, review of existing literature in this area shows contradicting findings and therefore, needs further investigation.

Even though numerous studies on knowledge and perception of safety and efficacy of generic drugs have been conducted in Malaysia, most of the studies were descriptive in nature (Hassali et al. 2014b; Kumar et al. 2015; Ting et al. 2016; Wong et al. 2014b)attitudes, and perceptions of generic medicines in low- and middleincome countries (LMICs. There are very limited empirical studies in this area conducted from marketing perspective using structural equation modelling. Therefore, this study could contribute to the literature in a way that the antecedents of purchase intention towards generic drugs were examined from the empirical perspective of marketing. Furthermore, prior studies that examined trust and perceived risk as two distinct constructs is very scarce. Thus, this study meets the gap by examining their relationships with each other, which will then influence purchase intention.

Perceived risk plays the most important role in purchase intention towards generic drugs. Previous studies by Abzakh et al. (2013), Zerbini et al. (2017), Francisquinho (2013), Colgan et al. (2015) and others showed that perceived risk is one of the key determinants of purchase intention in generic drugs. Numerous studies found that perceived risk is a strong determinants of purchase intention but did not emphasize on the specific risk dimensions which have distinct contribution on perceived risk towards generic drugs. As mentioned earlier, this study extends the model from Zerbini et al. (2017) and Abzakh et al. (2013). However, Zerbini et al. (2017) only measured two types of risk: physical risk and performance risk, whereas our study measures the perceived risk using a more comprehensive measure that comprises six elements of risk: financial risk, performance risk, psychological risk, physical risk, social risk and time risk. Therefore, this study closes the gap by identifying the dimensions of perceived risk that involve in generic drugs context which was lacking in prior generic drugs studies. In addition, Abzakh et al. (2013) only measured the relationship between different types of risks and consumer resistance towards generic drugs. Their study did not examine trust in pharmacist and purchase intention towards generic drugs.

\section{MANAGERIAL IMPLICATION}

The purpose of this study is to examine the factors that influence the purchase intention towards generic drugs.
The findings of this study are beneficial to government, policymakers, pharmaceutical manufacturers and marketers. For the government, there is an indirect implication from generic substitution. By examining factors that influence purchase intention of generic drugs, generic substitution rate could be improved. As a result, pharmaceutical spending can be reduced. Subsequently, healthcare services can be improved in terms of accessibility and affordability. The potential savings of pharmaceutical spending from generic substitution may be allocated to other healthcare services such as highly advanced and sophisticated medical equipment, facilities and medical talents. Therefore, better budget allocation in healthcare expenditure that could promote higher quality of healthcare services and more effective utilisation of income earned from tax could be achieved.

For policymakers and regulators like National Pharmaceutical Regulatory Agency (NPRA), the findings of this study could contribute to policy makers to widen the coverage area of public healthcare services especially to the rural areas in the country. Besides, new policy formulation and implementation can be executed more effectively. New policy such as stricter regulations for pharmaceutical manufacturers for higher safety profile and laboratory test on generic drugs will increase generic substitution rate. Besides, national medicine pricing policy can be formulated and implemented in order to control drug prices in both the public and private sector which then will decrease drug expenditure and enhance the medicine affordability in Malaysia.

Lastly, for pharmaceutical companies and marketers, a deeper insight into the factors that influence generic drug purchase intention could help them to focus on specific areas that have the most impact on the consumers. This could also assist them in planning effective marketing strategies to the target groups such as pharmacists, physicians and patients. For instance, the information about bioequivalence, quality, efficacy and safety of generic drugs need to be communicated to manufacturing companies, pharmacists, physicians and patients in order to change the perception towards generic drugs. By giving awareness to both manufacturing companies and public about the generic drugs, it could promote their usage and subsequently enhance sales.

\section{LIMITATION AND SUGGESTIONS FOR FUTURE RESEARCH}

There are several limitations in this study which lead to suggestions for future research. First, the sampling method used in this study is convenience sampling. Respondents were chosen based on easy accessibility, geographical proximity and known contacts due to limited time and financial resources. Generic drug purchasers in Malaysia are widely spread over to other states, including Sabah and Sarawak. Due to the small sample size, generalisation may not be valid and this may not represent the whole Malaysian's purchasing attitudes 
and behaviour towards generic drugs. Thus, these findings are not representative to other geographical or demographical contexts. It is suggested that larger sample size via probability sampling method is applied in future research.

Secondly, the research design used in this study is quantitative research approach via questionnaire survey method. The questionnaire used in this study was only prepared in English language. The questionnaire was not translated into other languages due to time and resource constraints, and risk of mistranslation. As such, the study is only accessible to those who understand English language and neglect other groups of individuals who cannot understand or comprehend English. For future research, it is recommended that the questionnaire form is translated into other languages, particularly Malay language as it is the official national language of the country and the fact that $67.4 \%$ of the Malaysian citizens are Malays (Department of Statistics Malaysia 2011). By translating the questionnaire into other languages such as Malay, Chinese and Tamil, it will allow more people to participate in the study and contribute to more meaningful findings.

Finally, past literature found that the causal relationship between trust and perceived risk is bidirectional, reciprocal and it is a non-recursive model. According to Hair et al. (2017), one of the limitations of PLS-SEM is it cannot be applied when the research model contains causal loops or circular relationships between the latent variables. Hence, future research on relationship between trust and perceived risk should employ other statistical method in order to understand the practical relationship between the two constructs.

\section{REFERENCES}

Abzakh, A.A., Ling, K.C. \& Alkilani, K. 2013. The impact of perceived risks on the consumer resistance towards generic drugs in the Malaysia Pharmaceutical Industry. International Journal of Business and Management 8(3): $42-50$.

Ajzen, I. 1985. Behavioral interventions based on the Theory of Planned Behavior. Action Control: 11-39.

Ajzen, I. 1991. The theory of planned behavior. Organizational Behavior and Human Decision Processes 50: 179-211.

Ajzen, I. 2010. Constructing a theory of planned behavior questionnaire. Biofeedback and Selfregulation 17: 1-7.

Awaisu, A., Kheir, N., Ibrahim, M.I.M., El-Hajj, M., Hazi, H., Khudair, N. \& Barazi, R. 2014. Knowledge, attitudes, and practices of community pharmacists on generic medicines in Qatar. International Journal of Clinical Pharmacy 36(2): 394-404.

Balasopoulos, T., Charonis, A., Athanasakis, K., Kyriopoulos, J. \& Pavi, E. 2017. Why do generic drugs fail to achieve an adequate market share in Greece? Empirical findings and policy suggestions. Health Policy 121(3): 265-272.

Cheng, H.H. \& Huang, S.W. 2013. Exploring antecedents and consequence of online group-buying intention: An extended perspective on theory of planned behavior. International Journal of Information Management 33(1): 185-198.
Chiu, C.M., Wang, E.T.G., Fang, Y.H. \& Huang, H.Y. 2014. Understanding customers' repeat purchase intentions in B2C e-commerce: The roles of utilitarian value, hedonic value and perceived risk. Information Systems Journal 24(1): 85-114.

Chopdar, P.K., Korfiatis, N., Sivakumar, V.J. \& Lytras, M.D. 2018. Mobile shopping apps adoption and perceived risks: A cross-country perspective utilizing the Unified Theory of Acceptance and Use of Technology. Computers in Human Behavior 86: 109-128.

Chua, G.N., Hassali, M.A., Shafie, A.A. \& Awaisu, A. 2010. A survey exploring knowledge and perceptions of general practitioners towards the use of generic medicines in the northern state of Malaysia. Health Policy 95(2-3): 229 235.

Cohen, J. 1988. The Effect Size index. Statistical Power Analysis for the Behavioral Sciences. New York: Lawrence Erlbaum Associates

Colgan, S., Faasse, K., Martin, L.R., Stephens, M.H., Grey, A. \& Petrie, K.J. 2015. Perceptions of generic medication in the general population, doctors and pharmacists: A systematic review. BMJ Open 5(12): 1-9.

Degirmenci, K. \& Breitner, M.H. 2017. Consumer purchase intentions for electric vehicles: Is green more important than price and range? Transportation Research Part D: Transport and Environment 51: 250-260.

Diamantopoulos, A. \& Siguaw, J.A. 2006. Formative versus reflective indicators in organizational measure development: A comparison and empirical illustration. British Journal of Management 17(4): 263-282

Featherman, M.S. \& Pavlou, P.A. 2003. Predicting e-services adoption: A perceived risk facets perspective. International Journal of Human Computer Studies 59(4): 451-474.

Ferreira, P. \& Barbosa, H. 2017. Choice of mandatory prescribed drugs in Portugal: A consumers' perspective. International Journal of Pharmaceutical and Healthcare Marketing 11(4): 439-454.

Fornell, C. \& Cha, J. 1994. Partial least squares. In Advanced methods of marketing research, edited by R. P. Bagozzi, 52-87.Cambridge, Mass: Blackwell Business.

Fornell, C. \& Larcker, D. 1994. Structural equation models with unobservable variables and measurement error: Algebra and statistics. Journal of Marketing Research 18(3): 382-388.

Forsythe, S.M. \& Shi, B. 2003. Consumer patronage and risk perceptions in Internet shopping. Journal of Business Research 56(11): 867-875.

Francisquinho, A. 2013. Consumer attitudes and perceptions towards medicine types: Brand medicine versus Generic Medicines. Available at https://repositorio.iscte-iul. pt/bitstream/10071/8012/1/FINAL_ TESE _ ANA FRANCISQUINHO.pdf

González, M. \& Brea, J. 2008. An investigation of the relationship among service quality, customer satisfaction and behavioural intentions in Spanish Health Spas in Spanish H. Journal of Hospitality and Leisure Marketing 13(July 2012): 66-90.

Haas, J.S., Phillips, K.A., Gerstenberger, E.P. \& Seeer, A.C. 2005. Potential savings from substituting generic drugs for brand-name drugs: Medical Expenditure Panel Survey, 1997-2000. Annals of Internal Medicine 142(11): 1997 2000.

Hair, J., Hult, T., Ringle, C. \& Sarstedt, M. 2014. A primer on Partial Least Squares Structural Equation Modeling (PLSSEM). Long Range Planning 46(s 1-2):184-185. 
Hair, J., Hult, T., Ringle, C., \& Sarstedt, M. 2017. A Primer on Partial Least Squares Structural Equation Modeling (PLS-SEM). 2nd edition. Thousand Oaks, CA: Sage.

Hair, J., Sarstedt, M., Pieper, T. \& Ringle, C. 2012. The use of Partial Least Squares Structural Equation Modeling in strategic management research: A review of past practices and recommendations for future applications. Long Range Planning 45(5-6): 320-340.

Hassali, M.A., Alrasheedy, A.A., McLachlan, A., Nguyen, T.A., Al-Tamimi, S.K., Ibrahim, M.I.M. \& Aljadhey, H. 2014a. The experiences of implementing generic medicine policy in eight countries: A review and recommendations for a successful promotion of generic medicine use. Saudi Pharmaceutical Journal 22(6): 491-503.

Hassali, M.A., Wong, Z.Y., Alrasheedy, A.A., Saleem, F., Mohamad Yahaya, A.H. \& Aljadhey, H. 2014b. Perspectives of physicians practicing in low and middle income countries towards generic medicines: A narrative review. Health Policy 117(3): 297-310.

Hassali, M., Alrasheedy, A., Chan, C., Saleem, F. \& Tangiisuran, B. 2014c. Knowledge and perceptions of physicians from private medical centres towards generic medicines in the State of Perak, Malaysia: Findings and implications. Journal of Medical Marketing 14(4): 212-219.

Jaafar, S.N., Lalp, P.E. \& Mohamed, M. 2013. Consumers' perceptions, attitudes and purchase intention towards private label food products in Malaysia. Asian Journal of Business and Management Sciences 2(8): 73-90.

Khadke, V.V. \& Khanda, S.Y. 2017. To study doctor's beliefs, barriers, awareness, and actual practices regarding use of generic medicines. International Journal of Basic \& Clinical Pharmacology 6(8): 1871-1879.

Kim, L.H., Kim, D.J. \& Leong, J.K. 2005. The effect of perceived risk on purchase intention in purchasing airline tickets online. Journal of Hospitality \& Leisure Marketing 13(2): 33-53.

Kumar, R., Hassali, M.A., Saleem, F., Alrasheedy, A.A., Kaur, N., Wong, Z.Y. \& Kader, M.A. 2015. Knowledge and perceptions of physicians from private medical centres towards generic medicines: A nationwide survey from Malaysia. Journal of Pharmaceutical Policy and Practice 8(1): 1-13.

Kumar, R., Hassali, M., Kaur, N. \& Kader, M. 2014. Perceptions of physicians from private medical centers in Malaysia about generic medicine usage: a qualitative study. Generics and Biosimilars Initiative Journal 3(2): 63-70.

Leisen, B. \& Hyman, M.R. 2004. Antecedents and consequences of trust in a service provider: the case of primary care physicians. Journal of Business Research 57(9): 990-999

Lewek, P., Smigielski, J. \& Kardas, P. 2015. Factors affecting the opinions of family physicians regarding generic drugs-a questionnaire based study. Bosnian Journal of Basic Medical Sciences 14(3): 45-50.

Mahdi, L.A., Kadhim, D.J. \& Al-Jumaili, A.A. 2020. Knowledge, perception and attitude regarding generic medicines among Iraqi physicians. Innovations in Pharmacy 11(1): 1-10.

Masood, I., Saleem, A. \& Jamshed, S.Q. 2016. Why do physicians prefer brand medicines over generic medicines in Pakistan? A quantitative approach. Journal of Pharmaceutical Health Services Research 7(4): 247-251.

Nunes, A.M., Ferreira, D.C., de Matos, A. \& Julião, R.M. 2020. The Portuguese generic medicines market: What's next? Health Policy 124(4): 397-403.
Peter, J.P., Ryan, M.J. \& Ryan, J. 1976. An investigation of perceived risk at the brand level. Journal of Marketing 13(2): 184-188.

Preacher, K.J., \& Hayes, A.F. 2004. SPSS and SAS procedures for estimating indirect effects in simple mediation models. Behavior Research Methods, Instruments, and Computers 36: 717-731

Preacher, K.J. \& Hayes, A.F. 2008. Asymptotic and resampling strategies for assessing and comparing indirect effects in multiple mediator models. Behavior Research Methods. 40: 879-889.

Rozano, M. \& Gomez, M. 2009. Intention to purchase generic drugs in a young market: perceived risk, prescribers and experience. European Marketing Academy: 1-21.

Shraim, N.Y., Al Taha, T.A., Qawasmeh, R.F., Jarrar, H.N., Shtaya, M.A.N., Shayeb, L.A. \& Sweileh, W.M. 2017. Knowledge, attitudes and practices of community pharmacists on generic medicines in Palestine: A crosssectional study. BMC Health Services Research 17(1): $1-9$.

Soper, D.S. 2018. A-priori sample size calculator for Multiple Regression [Software].

Srivastava, R. \& Kumar, S.J. 2014. Understanding of consumer's awareness about brands in pharmaceutical industry: An empirical study. Journal of Medical Marketing: Device, Diagnostic and Pharmaceutical Marketing 14(2-3): 99107.

Stone, R., \& Gronhaug, K. 1993. Perceived Risk: Further Considerations for the Marketing Discipline. European Journal of Marketing 27: 39-50.

Sullivan, G.M., \& Feinn, R. 2012. Using effect size - or why the $\mathrm{P}$ value is not enough. Journal of Graduate Medical Education.

Ting, C.Y., Lee, K.S., Tan, R.T.-H., Ang, W.C., \& Ming, L.C. 2016. An exploratory study on the consumers use of medicine in the state of Sarawak, Malaysia. Journal of Young Pharmacists 8(4): 477-482.

Thomson, M. 2006. Human brands: Investigating antecedents to consumers' strong attachments tocCelebrities. Journal of Marketing 70(3): 104-119.

Wajid, S., Al-Arifi, M.N., Al-Nomay, H.A., Al-Mousa, Y.N., \& Babelghaith, S.D. 2015. Knowledge and perception of community pharmacists ' towards generic medicines in Saudi Arabia. Biomedical Research 26(4): 800-806.

Wiedmann, K.P., Hennigs, N., Pankalla, L., Kassubek, M., \& Seegebarth, B. 2011. Adoption barriers and resistance to sustainable solutions in the automotive sector. Journal of Business Research 64(11): 1201-1206.

Wong, Z.Y., Hassali, M.A., Alrasheedy, A.A., Saleem, F., Yahaya, A.H.M. \& Aljadhey, H. 2014a. Malaysian generic pharmaceutical industries: Perspective from healthcare stakeholders. Journal of Pharmaceutical Health Services Research 5(4): 193-203.

Wong, Z.Y., Hassali, M.A., Alrasheedy, A.A., Saleem, F., Yahaya, A.H.M. \& Aljadhey, H. 2014b. Patients' beliefs about generic medicines in Malaysia. Pharmacy Practice 12(4): 474

Xu, K., Soucat, A., \& Kutzin, J. 2018. New perspectives on global health spending for universal health coverage. Geneva: World Health Organization. Available at http:// apps.who.int/iris/bitstream/handle/ 10665/259632/WHOHIS-HGF-HFWorkingPaper-17.10-engpdf;jsessionid=F D27C73861607BD2605E3EECE33CBBD6? sequence=1

Yousefi, N., Mehralian, G., Peiravian, F., Jahangiri, S. \& Ahmadi, R. 2015. Physicians' perceptions of generic 
medicine in Iran. Drugs and Therapy Perspectives 31(7): 244-250.

Zainul, E. 2018. Malaysia's healthcare industry to grow to RM80b by 2020 - Frost \& Sullivan. The Edge Market $1-7$.

Zerbini, C., Luceri, B. \& Vergura, D.T. 2017. Leveraging consumer's behaviour to promote generic drugs in Italy. Health Policy 121(4): 397-406.

\section{Hong Keai Sin}

Faculty of Business and Accountancy

University of Malaya

50603 Kuala Lumpur, MALAYSIA

E-Mail: cassiehong123@gmail.com

Kamisah Ismail (corresponding author)

Faculty of Business and Accountancy

University of Malaya

50603 Kuala Lumpur, MALAYSIA.

E-Mail:kamisah.ismail@um.edu.my 